\title{
可視的変形者に対する一般人の評価と認識 一写真刺激を用いて一
}

\author{
深谷 悦子, 岩滿 優美 \\ 北里大学大学院医療系研究科医療心理学 \\ キーワード : 可視的変形, 容貌, 写真, 評価, 認識
}

\begin{abstract}
Objective: This study aimed to assess how the general public perceives and evaluates people with visible differences.

Methods: This study targeted 153 university and graduate students. These students were shown four photographs, and were asked to anonymously answer an originally-developed questionnaire which included items on perception and evaluation of people with visible differences. After excluding questionnaires with missing values, we analyzed data from a total of 127 participants.

Results and Discussion: High evaluation scores were obtained for five items, including "readily catching the eyes of others" and "being surprised when running into them." This reflects difficulties experienced by people with visible differences. There were significant sex-differences in five items, including "being in a disadvantageous position when it comes to marriage" and "difficult to have a loving relationship with someone"; suggesting men evaluated people with visible differences more negatively than women. When assessing how participants perceived the reasons underlying the visible differences in free descriptions, the rate of correct answers differed by the specific reason. In particular, for portwine stain, even in the perception group are had a low rate. These findings highlight the importance of educating the general public so that they would have accurate knowledge regarding visible differences. Keywords: visible difference, appearance, photograph, evaluation, perception
\end{abstract}

\section{1. 背景・目的}

\section{1 可視的変形とは}

可視的変形とは，他者から観察可能な身体外表にあ る他者との差異を意味する言葉である。可視的変形は 様々な原因によって生じるが, 大きく先天性と後天性 に分けることができる。先天的な可視的変形の代表例
は 400 人〜 600 人に 1 人の割合で出生するといわれて いる口唇裂・口蓋裂1) であり, 後天的な可視的変形 の代表例は火傷である。可視的変形を抱える可視的変 形者は, 外国の調查では 111 人に 1 人いるといわれて いる2)。

このように, 可視的変形者の存在は少数とは言い難 いものの, 日本に扔いて可視的変形や可視的変形者に 関する研究は萌芽期にある ${ }^{3)}$ 。それゆえに, 可視的変

Perception and evaluation of people with visible differences by the general public: A study using photo stimuli Etsuko Fukaya, Yumi Iwamitsu

Graduate School of Medical Sciences, Kitasato University

Received April 29, 2018, Accepted November 15, 2018

J-STAGE Advance publication date: January 18, 2019, doi.org/10.5058/stresskagakukenkyu.2018002 
形はこれまで，様々な言葉で表現されてきた。可視的 変形について, 松本 $(1999)^{4)}$ は当初「疾患固有の容貌」 と表現し，西倉 $(2008)^{5)}$ は自身が可視的変形の当事 者でもあるジャーナリストの石井 $(2000)^{6)}$ の表現を 用いて「異形の人」と表現した。また, 当事者団体と して NPO 法人の設立や, 可視的変形者の体験談をま とめる等した石井・藤井・松本 $(2001)^{7)}$ は,「ユニー クフェイス」と表現した。可視的変形を意味する言葉 は, 英語圈においても変遷をたどっている。 Rumsey \& Harcourt $(2007)^{8)}$ は, Disfigurement, Abnormality, Deformity, Defectという従来用いられていた言 葉にはネガティブな意味が内包されているとし，かわ りにVisible Difference という言葉を用いることを提 案している。本研究では, こうした英語圈において生 じた流れを波み，松本 (2009) ${ }^{9)}$ がVisible Difference に対して用いた可視的変形という日本語訳を使用する こととした。

\section{2 可視的変形に関する研究}

現在, 可視的変形に関する研究が進んでいるアメリ カでは1940年代から, イギリスでは1960年代から様々 な活動や研究が行われており, 1980 年代以降, 容貌 への関心が急激に高まった 6) 10)。こうした流れの中, 可視的変形に関する研究は当初疾患別に進められてき たが，原因となる疾患が異なっていても心理社会的困 難が似通っていると報告されたことから，可視的変形 として研究されるようになってきている11) 12)。しか し, 日本に拈いて, 可視的変形は 1990 年代まで心理

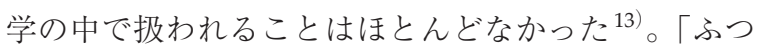
うの顔」をした人にとって，異形の顔を語ることは夕 ブー視されてきたのである ${ }^{6)}$ 。松本 $(2001)^{14)}$ は, 可 視的変形の特徴として, 他の障害と比較されやすく, 機能的な問題がない場合「たいしたことはない」と言 われやすいことを挙げている。また，西倉 (2015) ${ }^{15)}$ は 1995 年にイギリスで制定された障害差別禁止法と, 2013 年に日本で成立した障害者差別解消法の法案作 成過程における両国の当事者のロビー活動の違いに触 れた上で, 日本の可視的変形者にとっての切実な問題 は，社会における障害の枠組みではなく，個人におけ る心理的・情緒的次元の問題であると述べている。

このように, 日本は可視的変形に関して, 関心を示 してきたとは言い難い。しかし，可視的変形者は体験 談や研究の中で可視的変形に起因する様々な困

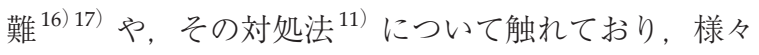
なストレスを抱えている。可視的変形による困難は特 に, 初対面や友人関係の構築 - 維持, 自尊感情の低下 等, 社会活動の様々な側面で生じる ${ }^{18)}$ 。また, 可視 的変形者の養育者をはじめとする周囲の人々も, 可視
的変形者との関わりに困難を抱えている ${ }^{19)}$ 20)。こう した可視的変形者と周囲の人々との相互の関わりに よって生じる困難について, 松本 (2006) ${ }^{21)}$ は, 可視 的変形に関連する心理社会的問題は, 人との関係を築 いていく中で徐々に生じてくると述べている。

こうした可視的変形者と周囲の人々の困難を理解す るためには, 可視的変形者に焦点を当てるだけでなく， 可視的変形者と接する機会の多くない一般の人々が, 可視的変形者に対してどのように評価しているのかを 明らかにすることが重要である。現在, 日本では, 前 述の通り可視的変形の当事者の語りによる心理社会的 困難とその対処, また, 可視的変形者の養育者の語り による心理社会的困難とその対処に焦点が当たってい る。しかし, 海外では, 教師が知的能力を過小評価す る22），電車で側に座ろうとしない23）といった報告が ある。可視的変形者に対するこうした評価は日本でも 十分生じうるだろう。そのため, 可視的変形者に対す る評価を明らかにすることは, 可視的変形者の心理社 会的困難の理解とその支援に重要である。また，一般 の人々の可視的変形に関する知識のなさと自身の行動 に対する確信のなさは, 初対面時の共感, ショック, 恐れ, 好奇心, 面白さ, 嫌悪といった反応と不安, 回 避, 同情といった行動に繋がっている24)。そのため, 可視的変形者とその周囲の人々, 両者の心理社会的困 難を理解し，支援を行う上で，可視的変形者と接する 機会の多くない一般の人々が可視的変形についてどの 程度の認識を持ち, 実際にはどのように認識している のかといった認識の内容を明らかにすることも重要で ある。

以上より, 本研究では第 1 に, 一般の人々が可視的 変形者の将来や生活, 対人関係等についてどう思うか という評価を明らかにすることを目的とする。第 $2 に ，$ 一般の人々の性別によって, 可視的変形者に対する評 価に差異が生じるかについて明らかにする。第 3 に， 一般の人々が可視的変形の原因についてどの程度認識 しており, 可視的変形の原因について実際にはどのよ うに認識しているのかを明らかにする。第 4 に, 可視 的変形者に対する評価の測定は日本において前例がな いことから, 可視的変形および可視的変形者, 並びに 本研究についての自由な感想について明らかにする。

これらから, 一般の人々の可視的変形者に対する捉 え方を検討することで, 本研究を可視的変形者と周囲 の人々の心理社会的困難の理解とその支援のための基 礎資料とする。また，一般の人々に対する教育のため の基礎資料とする。 


\section{2. 方 法}

\section{1 対象者}

質問紙調查を関東圈の一般大学・大学院 3 校で実施 した。質問紙を 153 部配布し, 151 名から回答を得た。 不備のあった回答を除外し, 127 名（男性 46 名, 女 性 81 名, 平均年齢 $\pm S D=22 \pm 1.93$ 歳）を分析対象と した。内， 7 名が自身に火傷や火傷によるケロイドが あると回答した。

\section{2 写真刺激}

可視的変形に関する活動を行っているイギリス国家 公認のチャリティ団体 Changing Faces が 2010 年に 行った The Children's Face Equality Campaignのポ スター写真 4 枚を, 使用許可を得た上で一部を切り取 り使用した（Appendix Figure 1)。

\section{3 質問項目}

一般大学院生 6 名（男性 2 名, 女性 4 名, 平均 $\pm S D$ $=28 \pm 5.26$ 歳) を対象に写真刺激を提示し, 印象や感 想等を自由に記述するよう求め, 予備調査を行った。 予備調査の結果と関連文献・書籍の内容を参考に, 著 者と臨床心理学の研究者 1 名の計 2 名で話し合いを行 い，以下の質問項目を独自に作成した。

2.3.1 印象

予備調查と林 $(1978)^{25)}$, 井上. 小林 $(1985)^{26)}$ 等 を基に，12 項目（7 件法の SD 法）とした。な押，全 項目の平均值が $\lceil 4=$ どちらともいえない」に近く(平 均 $\pm S D=4.03 \sim 4.83 \pm 0.66 \sim 0.78)$, 本研究では分析 しなかった。

\subsection{2 評価}

予備調查と石井他 $(2001)^{7)}$, 松本 - 石井 - 藤井 (2001) 27) 等を基に，15 項目（「1=そう思わない」〜 $\lceil 5=$ そう思う」の 5 件法）とした。

\subsection{3 認識の程度}

梶井・黑木 · 新井 $(2015)^{28)}$, 鈴木他 (1979) ${ }^{29)}$ 等 を基に，具体的な可視的変形を提示し，それぞれに対 して主観的な報告で「知っている」あるいは「知らな い」のいずれかに回答するよう求めた。なお，「知っ ている」と回答した場合には, 認識の経緯として「な ぜ知っているのか」, 主観的な認識の程度として「ど の程度知っていると思っているか」について回答する よう求めた。

\subsection{4 認識の内容}

各写真刺激の人物が可視的変形となった原因につ いて，思いつく原因を自由記述にて回答するよう求め た。

\subsection{5 感想}

各写真刺激および本研究についての感想を自由記述 で回答するよう求めた。なお，写真刺激ごとの感想に ついて, 本研究では分析しなかった。

\subsection{6 基本属性}

対象者の年齢，性別，所属を回答するよう求めた。

\section{4 手続き}

2016 年 10 月から 2017 年 5 月に, 各大学の教員の 協力を得て授業終了後に文書と口頭で研究の説明を行 い，集団形式で実施した。対象者は 4 枚の写真刺激に ついてそれぞれ写真刺激ごとに(1)印象，(2)評価，(4)認 識の内容，(5)感想について回答した。な押，4 枚の写 真刺激はカウンターバランスをとった。その後, (3)知 識, (5)感想, (6)基本属性について回答した。質問紙は 無記名で実施し，提出をもって研究参加の同意とみな した。質問紙回収後, 可視的変形に関する知識を記載 したプリントを用いて情報提供を行うことで，可視的 変形者を見たことで感じる恐れやショックを和らげる よう，また正しい情報を提供するよう配慮した。なお， 本研究は北里大学医療衛生学部研究倫理審査委員会の 承諾を得て実施した。

\section{5 分析の概略}

可視的変形者に対する評価の各々の得点の平均と $S D$ を算出した。また，対象者の性別による評価の違 いを検討するため, 15 項目の評価について $t$ 検定を 行った。な押, 分析では, 回答に 1 項目以上の久損が あった場合，その参加者を分析から除外した。

第 2 に, 認識の内容を検討するため, 写真刺激ごと に対象者の主観的報告を基に可視的変形の原因を 「知っている」という回答者を「認識群」「「知らない」 という回答者を「非認識群」としてそれぞれ2 群に分 けた。Appendix Figure 1.A（火傷）では, 認識群が 90 名, 非認識群が 37 名であり, Appendix Figure 1.B (頭蓋・前頭・鼻骨症候群) では, 認識群が 33 名, 非 認識群が 94 名であり, Appendix Figure 1.C と Appendix Figure 1.D (血管腫) では, 認識群が 16 名, 非認識群が 111 名であった。

4 枚の写真刺激について, Mayring (1995 小田・ 山本・春日他訳，2002（ ${ }^{30)}$ の方法を参考に，それぞれ 認識群と非認識群ごとに可視的変形の原因についての 認識の内容の自由記述を質的に分析した。まず，著者 が各自由記述から主要な表現と内容を抽出した。次 に，表現と内容を結びつけ，類似する内容をコード化 し，類似するコードを集め，サブカテゴリーおよびカ テゴリーに分類し，サブカテゴリー名拉よびカテゴ リー名を付けた。最後に, 著者と臨床心理学の研究者 
1名がコードとカテゴリーについて意見が一致するま で検討と議論を繰り返し, 内的妥当性を検証した。群 ごとに総コード数を $100 \%$ として，カテゴリーとサブ カテゴリーのそれぞれの割合をパーセンテージで示し た。感想の自由記述について, Schlosberg, H の感情

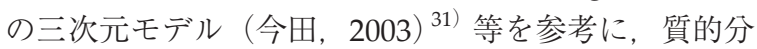
析を行った。

\section{3. 結 果}

\section{1 可視的変形者に対する評価}

Table 1 は, 可視的変形者に対する評価の各々の得 点の平均 $\pm S D$ を示している。評価では, 全ての項目 が $2.03 \pm 0.67$ 点以上で, $33=$ どちらともいえない」に 近かった。中間点の「3=どちらともいえない」より 得点が高かった評価項目は「他者や周囲から視線を向 けられやすい」，「出会ったときに驚く」，「いじめられ やすい」,「同情されやすい」，「恋愛をするのが大変」 の 5 項目であった。

\section{2 性別による評価の違い}

性別による評価の違いを検討するため, 性別（男性・ 女性）を 2 群に分け， $t$ 検定を行った（Table 1 参照）。

その結果, 「結婚上の不利がある」,「恋愛をするの が大変」,「友人ができにくい」,「いじめられやすい」, 「おしゃれしづらい」の 5 項目で有意な差が認められ た $(t(125)=2.03, p<.05)$ 。これら全ての項目で, 男 性は女性と比較して得点が高かった。

\section{3 可視的変形に関する認識の程度と可視的变形 の原因についての認識の内容}

可視的変形の原因についての実際の認識を検討する ため, 原因 (写真刺激) ごとに対象者の主観的な報告 を基に認識の程度を「認識群」と「非認識群」の 2 群 に分け, 群ごとに可視的変形の原因に関する自由記述 の質的分析を行った。以下，[] をカテゴリー,〈〉 をサブカテゴリー, “”をコードとした。その結果,

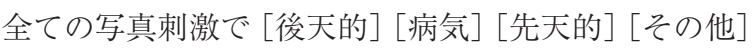
の 4 カテゴリーが抽出された。

Table 2 は, 認識群と非認識群の火傷の写真に対する 質的分析の結果を示している。最も出現頻度が多かっ たカテゴリーは, [後天的］が認識群で $63.8 \%$, 非認 識群で $56.3 \%$ であった。認識群では, 出現頻度が多 かったサブカテゴリーは, 〈事故〉が $21.6 \%$, 〈病気〉が $17.2 \%$ であった。正答の〈火傷〉の出現率は $32.8 \%$ で あった。非認識群では, 出現頻度が多かったサブカテ ゴリーは, 誤答の〈病気〉が $28.1 \%$, 〈事故〉が $25.0 \%$ であった。正答の〈火傷〉の出現率は $18.8 \%$ であった。

Table 3 は, 認識群と非認識群の頭蓋・前頭・鼻骨 症候群に対する質的分析の結果を示している。最も出 現頻度が多かったカテゴリーは, [先天的 ] が認識群 で $54.1 \%$ ，非認識群で $71.8 \%$ であった。認識群では， 出現頻度が多かったサブカテゴリーは, 誤答の〈生ま れつき〉の $32.4 \%$ であり, 正答の〈遺伝〉と〈先天 性奇形〉の出現率はそれぞれ $16.2 \%, 5.4 \%$ のため, 正答率は合計 $21.6 \%$ であった。非認識群では, 出現 頻度が多かったサブカテゴリーは，誤答の〈生まれつ

Table 1 評価に関する平均值および男性群と女性群の $t$ 検定について

\begin{tabular}{|c|c|c|c|c|c|c|c|}
\hline & \multicolumn{2}{|c|}{ 全体（n=127） } & \multicolumn{2}{|c|}{ 男性（n=46） } & \multicolumn{3}{|c|}{ 女性（n=81） } \\
\hline & 平均值 & $(S D)$ & 平均値 & $(S D)$ & 平均值 & $(S D)$ & \\
\hline 他者や周囲から視線を向けられやすい & 3.82 & $(0.62)$ & 3.85 & $(0.67)$ & 3.80 & $(0.59)$ & \\
\hline 出会ったときに驚く & 3.43 & $(0.77)$ & 3.44 & $(0.86)$ & 3.42 & $(0.73)$ & \\
\hline いじめられやすい & 3.36 & $(0.73)$ & 3.54 & $(0.70)$ & 3.26 & $(0.74)$ & * \\
\hline 同情されやすい & 3.36 & $(0.73)$ & 3.39 & $(0.63)$ & 3.35 & $(0.79)$ & \\
\hline 恋愛をするのが大変 & 3.21 & $(0.84)$ & 3.49 & $(0.75)$ & 3.05 & $(0.85)$ & ** \\
\hline おしゃれしづらい & 2.99 & $(0.84)$ & 3.19 & $(0.87)$ & 2.88 & $(0.80)$ & * \\
\hline 結婚上の不利がある & 2.88 & $(0.94)$ & 3.22 & $(0.83)$ & 2.69 & $(0.90)$ & ** \\
\hline 就職上の不利がある & 2.84 & $(0.91)$ & 2.88 & $(9.48)$ & 2.81 & $(0.89)$ & \\
\hline 初対面で他者に与える印象が悪い & 2.79 & $(0.77)$ & 2.93 & $(0.80)$ & 2.70 & $(0.74)$ & \\
\hline 他者や周囲から軽んじられる & 2.66 & $(0.90)$ & 2.85 & $(0.90)$ & 2.55 & $(0.88)$ & \\
\hline 友人ができにくい & 2.56 & $(0.76)$ & 2.80 & $(0.79)$ & 2.69 & $(0.82)$ & ** \\
\hline 外見に気を使うべき & 2.49 & $(0.83)$ & 2.59 & $(0.89)$ & 2.44 & $(0.80)$ & \\
\hline 将来のために努力をするべき & 2.38 & $(0.86)$ & 2.50 & $(0.87)$ & 2.32 & $(0.85)$ & \\
\hline 他者や周囲とのコミュニケーションが苦手 & 2.34 & $(0.69)$ & 2.45 & $(0.76)$ & 2.28 & $(0.64)$ & \\
\hline 性格がゆがんでいる & 2.03 & $(0.67)$ & 2.15 & $(0.74)$ & 1.96 & $(0.62)$ & \\
\hline
\end{tabular}

${ }^{* *} p<.01,{ }^{*} p<.05$

注）「1=そう思わない」〜「5=そう思う」 
Table 2 認識群と非認識群の火傷に関する認識の内容について

\begin{tabular}{|c|c|c|c|c|c|}
\hline 群 & カテゴリー & 頻度（\%） & サブカテゴリー & 頻度（\%） & コード \\
\hline \multirow{10}{*}{ 認識群 } & \multirow{4}{*}{ 後天的 } & \multirow{4}{*}{74 (63.8) } & 火傷 & $38(32.8)$ & 火傷, 火傷によるケロイド \\
\hline & & & 事故 & $25(21.6)$ & 事故，事故などの後遺症 \\
\hline & & & 外傷 & $10 \quad(8.6)$ & ケガ \\
\hline & & & 手術 & $1 \quad(0.9)$ & 手術痕 \\
\hline & \multirow{2}{*}{ 病気 } & \multirow{2}{*}{$23(19.8)$} & 病気 & $20(17.2)$ & 病気 \\
\hline & & & 副作用 & $3 \quad(2.6)$ & 治療の副作用, 薬の副作用 \\
\hline & \multirow{2}{*}{ 先天的 } & \multirow{2}{*}{$15(12.9)$} & 生まれつき & $13(11.2)$ & 生まれつき \\
\hline & & & 遺伝 & $2 \quad(1.7)$ & 遺伝的疾患 \\
\hline & \multirow{2}{*}{ その他 } & \multirow{2}{*}{$4 \quad(3.4)$} & 作り物 & $3 \quad(2.6)$ & 画像編集ソフトによる加工 \\
\hline & & & その他 & $1 \quad(0.9)$ & ストレス \\
\hline \multirow{7}{*}{ 非認識群 } & \multirow{4}{*}{ 後天的 } & \multirow{4}{*}{$18(56.3)$} & 事故 & $8(25.0)$ & 事故 \\
\hline & & & 火傷 & $6(18.8)$ & 火傷, 火傷の痕 \\
\hline & & & 外傷 & $2 \quad(6.3)$ & ケガ, 体罰 \\
\hline & & & その他 & $2 \quad(6.3)$ & 義眼, 皮膚移植 \\
\hline & \multirow{2}{*}{ 病気 } & \multirow{2}{*}{$10(31.3)$} & 病気 & $9(28.1)$ & 病気 \\
\hline & & & 副作用 & $1 \quad(3.1)$ & 薬の副作用 \\
\hline & 先天的 & $4(12.5)$ & 生まれつき & $4(12.5)$ & 生まれつき \\
\hline
\end{tabular}

注) 認識群 : $\mathrm{n}=77$, コード総数 116 , 非認識群 : $\mathrm{n}=24$, コード総数 32

Table 3 認識群と非認識群の頭蓋・前頭・鼻骨症候群に関する認識の内容について

\begin{tabular}{|c|c|c|c|c|c|}
\hline 群 & カテゴリー & 頻度（\%） & サブカテゴリー & 頻度（\%） & コード \\
\hline \multirow{8}{*}{ 認識群 } & \multirow{3}{*}{ 先天的 } & \multirow{3}{*}{$20(54.1)$} & 生まれつき & $12(32.4)$ & 生まれつき \\
\hline & & & 遺伝 & $6(16.2)$ & 遺伝 \\
\hline & & & 先天性奇形 & $2 \quad(5.4)$ & 生まれつきの奇形 \\
\hline & \multirow{3}{*}{ 後天的 } & \multirow{3}{*}{$12(32.4)$} & 外傷 & $5(13.5)$ & ケガ, 骨折 \\
\hline & & & 事故 & $4(10.8)$ & 事故 \\
\hline & & & 手術 & $3 \quad(8.1)$ & 手術, 整形 \\
\hline & 病気 & $4(10.8)$ & 病気 & $4(10.8)$ & 病気 \\
\hline & その他 & $1 \quad(2.7)$ & 作り物 & $1 \quad(2.7)$ & 画像編集ソフトによる加工 \\
\hline \multirow{7}{*}{ 非認識群 } & \multirow{2}{*}{ 先天的 } & \multirow{2}{*}{$56(71.8)$} & 生まれつき & $41(52.6)$ & \multirow{2}{*}{$\begin{array}{l}\text { 生まれつき } \\
\text { 遺伝 }\end{array}$} \\
\hline & & & 遺伝 & $15(19.2)$ & \\
\hline & \multirow{4}{*}{ 後天的 } & \multirow{4}{*}{$17(21.8)$} & 事故 & 8(10.3) & 事故 \\
\hline & & & 外傷 & $5 \quad(6.4)$ & ケガ, 骨折 \\
\hline & & & 手術 & $3 \quad(3.8)$ & 手術 \\
\hline & & & その他 & $1 \quad(1.3)$ & 難産 \\
\hline & 病気 & $5 \quad(6.4)$ & 病気 & $5 \quad(6.4)$ & 病気 \\
\hline
\end{tabular}

注) 認識群 : $\mathrm{n}=26$, コード総数 37 , 非認識群 : $\mathrm{n}=63$, コード総数 78

き〉の $52.6 \%$ であり, 正答の〈遺伝〉は $19.2 \%$ で, 〈先 天性奇形〉という回答はなかった。

Table 4 は，認識群と非認識群の血管腫（Appendix Figure 1.C）に対する質的分析の結果を示している。 最も出現頻度が多かったカテゴリーは，[後天的］が 認識群で $38.7 \%$, 非認識群で $43 \%$ であった。認識群 では，出現頻度が多かったサブカテゴリーは，誤答の 〈火傷〉が $28.6 \%$, 〈病気〉が $14.3 \%$ であり, 正答の〈ア ザ〉の出現率は 9.5\%であった。非認識群では, 出現 頻度が多かったサブカテゴリーは，誤答の〈火傷〉が
$23.5 \%$ ，〈病気〉が $16.8 \%$, 〈生まれつき〉が $14.1 \%$ で あり，正答の〈アザ〉の出現率は $1.3 \%$ であった。

Table 5 は，認識群と非認識群の血管腫（Appendix Figure 1.D）に対する質的分析の結果を示している。 最も出現頻度が多かったカテゴリーは, [後天的］が 認識群で $40.7 \%$, 非認識群で $49.6 \%$ であった。認識群 では，出現頻度が多かったサブカテゴリーは，誤答の 〈火傷〉, 〈病気〉,〈アレルギー〉,〈生まれつき〉 $(18 \%$ 以上）であり，正答の〈アザ〉の出現率は $3.7 \%$ であっ た。非認識群では, 出現頻度が多かったサブカテゴリー 
Table 4 認識群と非認識群の Appendix Figure 1.C 血管腫に関する認識の内容について

\begin{tabular}{|c|c|c|c|c|c|}
\hline 群 & カテゴリー & 頻度（\%) & サブカテゴリー & 頻度（\%） & コード \\
\hline \multirow{10}{*}{ 認識群 } & \multirow{3}{*}{ 後天的 } & \multirow{3}{*}{$8(38.1)$} & 火傷 & $6(28.6)$ & 火傷 \\
\hline & & & 事故 & $1 \quad(4.8)$ & 事故 \\
\hline & & & 外傷 & $1 \quad(4.8)$ & 器質因 \\
\hline & \multirow{3}{*}{ 病気 } & \multirow{3}{*}{$7(33.3)$} & 病気 & $3(14.3)$ & 病気 \\
\hline & & & 皮膚の病気 & $2 \quad(9.5)$ & 皮膚病 \\
\hline & & & アレルギー & $2 \quad(9.5)$ & アレルギー, アトピー \\
\hline & \multirow{3}{*}{ 先天的 } & \multirow{3}{*}{$5(23.8)$} & 生まれつき & $2 \quad(9.5)$ & 生まれつき \\
\hline & & & アザ & $2 \quad(9.5)$ & 生まれつきのアザ \\
\hline & & & 遺伝 & $1 \quad(4.8)$ & 遺伝 \\
\hline & その他 & $1 \quad(4.8)$ & 作り物 & $1 \quad(4.8)$ & 画像編集ソフトによる加工 \\
\hline \multirow{13}{*}{ 非認識群 } & \multirow{4}{*}{ 後天的 } & \multirow{4}{*}{$64(43.0)$} & 火傷 & $35(23.5)$ & 火傷 \\
\hline & & & 事故 & $19(12.8)$ & 事故, 火事 \\
\hline & & & 暴力 & $7 \quad(4.7)$ & 暴力, 虐待, いじめ \\
\hline & & & 外傷 & $3(2.0)$ & ケガ, 虫刺され \\
\hline & \multirow{5}{*}{ 病気 } & \multirow{5}{*}{$57(38.3)$} & 病気 & $25(16.8)$ & 病気, 病気の後遺症 \\
\hline & & & アレルギー & $19(12.8)$ & アレルギー, アトピー \\
\hline & & & 皮膚の病気 & $9 \quad(6.0)$ & 皮膚病 \\
\hline & & & その他 & $3 \quad(2.0)$ & 肌が弱い, 乾燥 \\
\hline & & & 副作用 & $1 \quad(0.7)$ & 薬の副作用 \\
\hline & \multirow{3}{*}{ 先天的 } & \multirow{3}{*}{$27(18.1)$} & 生まれつき & $24(14.1)$ & 生まれつき \\
\hline & & & 遺伝 & $4 \quad(2.7)$ & 遺伝 \\
\hline & & & アザ & $2 \quad(1.3)$ & 生まれつきのアザ \\
\hline & その他 & $1 \quad(0.7)$ & その他 & $1 \quad(0.7)$ & 体質 \\
\hline
\end{tabular}

注) 認識群 : $\mathrm{n}=16$, コード総数 21 , 非認識群 : $\mathrm{n}=98$, コード総数 149

は, 誤答の〈火傷〉, 〈病気〉, 〈アレルギー〉, 〈生まれ つき〉 $(12 \%$ 以上）であり，正答の〈アザ〉の出現率 は $3.5 \%$ であった。

\section{4 本研究についての感想}

本研究についての感想の質的分析の結果， [可視的 変形］ [可視的変形以外] [₹の他］という3つのカテ ゴリーが抽出された（Table 6 参照）。[可視的変形］ では, 〈他人種の影響〉, 〈見た目の影響〉, 〈恐れ・苦 しみ〉などが, [可視的変形以外] では, 〈表情〉〈䨌 囲気〉〈姿勢〉〈服装〉が抽出された。[その他］では, 〈気づき〉, 〈当事者〉, 〈同情〉などが抽出された。

\section{4. 考察}

\section{1 可視的変形者に対する評価}

まず，本研究の第 1 の目的である可視的変形者に対 する評価について，「他者や周囲から視線を向けられ やすい」,「出会ったときに驚く」,「いじめられやすい」, 「同情されやすい」，「恋愛をするのが大変」の 5 項目 が「どちらともいえない」より得点が高く, 一般の人々 が，可視的変形者がこうした困難に直面していると捉
えられていることがわかった。これらの困難は石井他 $(2001)^{7)}$ の中で, 可視的变形の当事者の心理社会的 困難として述べられていることから，一般の人々が捉 える可視的变形者の心理社会的困難が同様であるとわ かった。松本 (2001) ${ }^{14)}$ が述べたように，可視的変形 は「たいしたことはない」と言われやすいが，本研究 の結果は可視的変形者と周囲の人々の困難を理解し, ストレスを和らげるための一助となるだろう。

しかし，「就職上の不利がある」については，先行 研究で可視的変形者が就職上不利であるということが 明らかになっているにもかかわらず32)，「どちらでも ない」よりやや得点が低かった。一般の人々が可視的 変形の存在が就職の困難につながらないと捉えた一 方, 藤井 (2001) ${ }^{33)}$ では可視的変形者が就職場面で直 面した様々な困難について述べている。以上より，就 職で可視的変形者が体験する心理社会的困難と, 一般 の人々が捉える可視的变形者の心理社会的困難には差 がある可能性が考えられる。また, 可視的変形の当事 者が自らについて，「おしゃれしづらい」，「外見に気 をつかうべき」と感じており, 周囲の人々も同様に感 じていると考えている5) 7) という点は, 本研究では示 されなかった。 
Table 5 認識群と非認識群の Appendix Figure 1.D 血管腫に関する認識の内容について

\begin{tabular}{|c|c|c|c|c|c|}
\hline 群 & カテゴリー & 頻度（\%） & サブカテゴリー & 頻度（\%) & コード \\
\hline \multirow{11}{*}{ 認識群 } & \multirow{4}{*}{ 後天的 } & \multirow{4}{*}{$11(40.7)$} & 火傷 & $5(18.5)$ & 火傷, 火傷の痕 \\
\hline & & & 事故 & $3(11.1)$ & 事故 \\
\hline & & & 外傷 & $2 \quad(7.4)$ & ケガ \\
\hline & & & 暴力 & $1 \quad(3.7)$ & 暴力 \\
\hline & \multirow{3}{*}{ 先天的 } & \multirow{3}{*}{ 8（29.6） } & 生まれつき & $5(18.5)$ & 生まれつき \\
\hline & & & 遺伝 & $2 \quad(7.4)$ & 遺伝 \\
\hline & & & アザ & $1 \quad(3.7)$ & 生まれつきのアザ \\
\hline & \multirow{3}{*}{ 病気 } & \multirow{3}{*}{$7(25.9)$} & 病気 & $3(11.1)$ & 病気 \\
\hline & & & アレルギー & $3(11.1)$ & アレルギー, アトピー \\
\hline & & & 皮膚の病気 & $1 \quad(3.7)$ & 皮膚病 \\
\hline & その他 & $1 \quad(3.7)$ & 作り物 & $1 \quad(3.7)$ & 画像編集ソフトによる加工 \\
\hline \multirow{11}{*}{ 非認識群 } & \multirow{4}{*}{ 後天的 } & \multirow{4}{*}{$70(49.6)$} & 火傷 & $32(22.7)$ & 火傷 \\
\hline & & & 事故 & $15(10.6)$ & 事故, 火事 \\
\hline & & & 暴力 & $14 \quad(9.9)$ & 暴力, 虐待, いじめ \\
\hline & & & 外傷 & $6 \quad(6.4)$ & ケガ, 打撲 \\
\hline & \multirow{4}{*}{ 病気 } & \multirow{4}{*}{$41(29.1)$} & 病気 & $18(12.8)$ & 病気, 病気の後遺症 \\
\hline & & & アレルギー & $18(12.8)$ & アレルギー, アトピー, じんましん \\
\hline & & & 皮膚の病気 & $4 \quad(2.8)$ & 皮膚病 \\
\hline & & & その他 & $1 \quad(0.7)$ & 肌が弱い, 乾燥 \\
\hline & 先天的 & \multirow[t]{2}{*}{$23(16.3)$} & 生まれつき & $18(12.8)$ & 生まれつき \\
\hline & \multirow[b]{2}{*}{ その他 } & & 17 & J (J.J) & 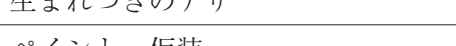 \\
\hline & & $7 \quad(5.0)$ & 作り物 & $\begin{array}{ll}1 & (0.7) \\
6 & (13)\end{array}$ & $\begin{array}{l}\text { ペイント, 仅装 } \\
\text { 充血炎症休啠 }\end{array}$ \\
\hline
\end{tabular}

注) $\mathrm{n}=29$, コード総数 42

本研究では, 評価の全項目の得点が「どちらでもな い」に近かったことから，可視的変形者に対する評価 が否定的と言い切ることはできない。この理由として, 感想から〈他人種の影響〉が得られたことや，顔を識 別する際，他人種よりも自人種において正答率が高 ( $^{34)}$ ことから, 本研究で使用した写真刺激が自人種 のものではなかったことによる影響が考えられる。ま た，後述の通り可視的変形以外の要因が評価に肯定的 に作用している可能性が考えられる。

\section{2 性別による可視的変形者に対する評価の違い}

次に, 第 2 の目的である一般の人々の性別によって, 可視的変形者に対する評価に違いが生じるかについ て,「結婚上の不利がある」,「恋愛をするのが大変」,「友 人ができにくい」,「いじめられやすい」，「おしゃれし づらい」の 5 項目で性差が認められた。以上より, 男 性は女性と比較して, 可視的変形の存在が友人関係の 構築や恋愛，結婚といった対人関係に扔いて不利に作 用し，装いにも影響すると捉えていることがわかった。 親しい関係性では，男性は女性よりも相手の身体的魅 力を重視する ${ }^{36)}$ ことがわかって扮り，本研究でも， 性差や関倸性が何らかの影響を书よぼした可能性が考
えられる。今後, 可視的変形者側のどのような要因が 評価に影響するのか，さらなる検討が必要である。

\section{3 可視的変形に関する認識の程度と認識の内容}

第 3 の目的である一般の人々が可視的変形の原因に ついてどの程度の認識をしており, 可視的変形の原因 について実際にはどのように認識しているのかについ て検討したところ，一部の原因があまり知られておら ず，可視的変形に関する認識が正確ではない可能性が 認められた。

後天的な可視的変形の火傷では, 認識群の $63.8 \%$, 非認識群の $56.3 \%$ と両群の半数以上から [後天的] な原因で可視的変形が生じたと正しく認識されてい た。また，先天的な可視的変形の頭蓋・前頭・鼻骨症 候群では, 認識群の $54.1 \%$, 非認識群の $71.8 \%$ と両群 の半数以上から [先天的] な原因で可視的変形が生じ たと認識されていた。しかし, 頭蓋 ·前頭 - 鼻骨症候 群の認識群では, [先天的] な原因の内, 誤答の〈生 まれつき〉の $32.4 \%$ という回答が最も多かった。頭蓋. 前頭・鼻骨症候群を知っていたため, 先天的な可視的 変形であることは認識できたものの, 正確な知識がな く,〈生まれつき〉という回答が多くなった可能性が 
Table 6 本研究についての感想

\begin{tabular}{|c|c|c|}
\hline カテゴリー & サブカテゴリー & コード \\
\hline \multirow{8}{*}{ 可視的変形 } & & こわい \\
\hline & 恐れ・苦しみ & 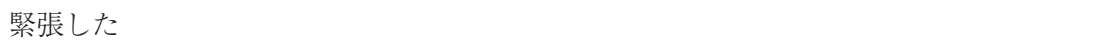 \\
\hline & & 見ているのがつらい \\
\hline & 驚き & $\begin{array}{l}\text { 驚いた } \\
\text { 探ってしまう }\end{array}$ \\
\hline & 嫌悪 & $\begin{array}{l}\text { 気分が悪くなった } \\
\text { 目を背けたくなった }\end{array}$ \\
\hline & 見た目 & $\begin{array}{l}\text { 顔よりも, 皮膚の方が印象形成に役割を果たしている } \\
\text { 肌の色や顔の部位の形で全体の印象が変わる } \\
\text { 顔のもたらす影響を実感した }\end{array}$ \\
\hline & 軽雮 & 偏見を持っていた \\
\hline & 他人種 & 外国人なので, そこまで違和感を感じない \\
\hline \multirow{4}{*}{$\begin{array}{l}\text { 可視的変形 } \\
\text { 以外 }\end{array}$} & 表情 & $\begin{array}{l}\text { 表情によって, 印象は左右される } \\
\text { 笑顔によって, プラスの印象をもっ } \\
\text { 表情で回答した }\end{array}$ \\
\hline & 雰囲気 & $\begin{array}{l}\text { 目から得られる全ての情報を統合する必要があると思った } \\
\text { 䨌囲気で回答した }\end{array}$ \\
\hline & 姿勢 & $\begin{array}{l}\text { ポーズによって, プラスの印象をもつ } \\
\text { 姿勢など身体的特徵以外の情報もかなり影響した }\end{array}$ \\
\hline & 服装 & 服装など身体的特徵以外の情報もかなり影響した \\
\hline \multirow{6}{*}{ その他 } & 気付き & $\begin{array}{l}\text { 偏見を持ち過ぎていた, 反省 } \\
\text { 差別をしていないつもりだったが, 自分は外見で人を判断していると落ち込んだ } \\
\text { 外見が人と違っている人を気にしていないつもりだったが, 意図的に気にしないように } \\
\text { していた }\end{array}$ \\
\hline & 当事者として & $\begin{array}{l}\text { ケロイドは自分にあって, 見られなくない気持ちがあるので, 顔にあったらと思うと複 } \\
\text { 雑な気持ちになった } \\
\text { 私も顔が赤くなるので, 印象は何か変わるのかなと思った } \\
\text { 自分は手にケロイドがあるが, こんな風になる人もいるのかと思った }\end{array}$ \\
\hline & 同情 & $\begin{array}{l}\text { 外見で決められることに，違和感を覚えた } \\
\text { 「努力をすべき」「気をつかうべ」と強く思う人がいたとしたら悲しい } \\
\text { 少しでも生活しやすい社会になったらいい }\end{array}$ \\
\hline & 写真の限界 & 写真と実際に見るのと, 印象が変わると思った \\
\hline & 教育 & 血管腫という疾患が存在することを初めて知った, 知る機会を得られてよかった \\
\hline & ケア & 精神的なダメージを受ける質問なので, ケアは充分に行う必要がある \\
\hline
\end{tabular}

注) $\mathrm{n}=29$, コード総数 42

考えられる。

また, 先天的な可視的変形の血管腫では，血管腫に ついて「知っている」と報告した認識群でも $38.1 \%$ と $40.7 \%$ が [後天的］な原因で可視的変形が生じた と認識しており, 認識が誤っていた。また,「知らない」 と報告した非認識群では， $38.3 \%$ と $29.1 \%$ が [病気］ が原因だと誤って認識していたことに加え，〈暴力〉 という誤った認識が $4.7 \%$ と $9.9 \%$ であり, 正答の〈ア ザ〉の $1.3 \%$ と $3.5 \%$ より多かった。血管腫がアザ であることは認識できたものの，先天的に生じる血管 腫という〈アザ〉についての知識がなく, 誤って〈暴 力〉が原因だと認識した可能性が考えられる。
前述の通り，一部の原因において実際の可視的変形 の原因と一般の人々の捉え方の間に差異があった。こ うした認識の誤りは, 可視的変形者とその養育者等の 周囲の人々に対する誤解や偏見等の心理社会的困難に

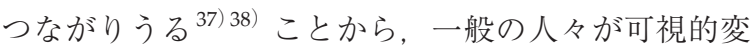
形に関する正しい知識や認識を持つことが重要である といえる。今後, 日本においてもChanging Facesが 提供するような教育 ${ }^{39)}$ を提供することが重要である と考えられる。

\section{4 本研究についての感想}

第 4 の目的である可視的変形および可視的変形者, 
並びに本研究についての自由な感想から, 評価では測 定することのできない一般の人々の可視的変形者の捉 え方についての反応が得られた。まず，〈恐れ・苦し み〉, 〈驚き〉, 〈嫌悪〉,〈軽荗〉といった感情の反応は, Partridge $\left.(1990,1993)^{40)}{ }^{41}\right)$ が可視的変形者の対人関 係を理解する為の手がかりとして提唱したSCARED 症候群 (脅かされ症候群 ${ }^{42}$ ) の内容と重なっていた。 このことから, 本研究で得られた感情の反応は, 可視 的変形者と出会った際の通常の反応と考えられる。し かし，こうした感情は感想から得られたような〈気付 き〉をもたらした可能性が考えられる。今後, こうし た〈気付き〉に対して, 可視的変形や可視的変形者に 関する正確な知識を提供する教育や，〈ケア〉を行っ てストレスを和らげる等，一般の人々に対する支援も 重要だろう。また，表情や服装といった[可視的変形 以外]の要因が一般の人々の可視的変形者の捉え方に 影響を与えている可能性が示唆されたことから，可視 的変形者自身が SCARED 症候群による反応 ${ }^{42}$ をコン トロールする方法を学ぶことも重要と思われる。

\section{5 本研究の限界}

本研究では, 使用した写真刺激が自人種のものでは なかったことに加え, 写真刺激の表情や服装等の可視 的変形者側の要因を統制できなかった。また，認識の 程度と認識の内容に関する一部の認識群の結果から, 認識の誤りが示唆されたが，主観的な報告で可視的変 形に関する認識の程度と認識の内容を測定したため, 認識が正確ではない可能性があり, 認識の程度や認識 の内容が及ぼす影響を検討できなかった。今後，可視 的変形に関する社会的な理解を求め, 可視的変形者と 周囲の人々が感じるストレスを減らしていくために も, 可視的変形者側の要因を統制し，一般の人々と可 視的変形者間の性別・年齢等も考慮した, より多角的 な評価の測定が必要だろう。また，一般の人々の認識 の程度, 認識の内容を客観的に測定して評価に与える 影響を検討し，教育的介入の効果を測定すること等も 必要である。感想から〈写真の限界〉が得られたよう に，写真刺激だけで可視的変形者の捉え方を検討する ことは限界がある。本研究で考慮できなかった社会的 望ましさの影響を考え, IAT を用いる等 ${ }^{35)}$, 研究方法 を検討すること, 得られた結果が実際の可視的変形者 の捉え方にどの程度反映されるかという検討も必要だ ろう。

\section{5. 結 論}

評価に扔いて，全体的に否定的ではなかったものの 「他者や周囲から視線を向けられやすい」,「出会った

ときに驚く」等, 5 項目で否定的な評価が認められた。 性別による評価の違いについては,「結婚上の不利が ある」，「恋愛をするのが大変」等，5 項目で男性は女 性と比較して可視的変形者に対してより否定的な評価 であった。

可視的変形の原因について, 実際の認識について検 討を行ったところ, 先天的な可視的変形である血管腫 について後天的な原因や病気が原因の可視的変形であ ると認識されていたことから，一部の可視的変形に関 する認識が正確ではない可能性がわかった。そのため, 一般の人々が可視的変形に関する正しい知識を持つた めの教育の重要性が示唆された。

なお，本研究では，写真を刺激に用いていること， 写真の対象者が外国人であり，それぞれの表情や姿勢 が異なっていることから，評価に影響を与えた可能性 が考えられる。今後, この点について注意して継続し て研究を扮こなっていきたい。

A 火傷

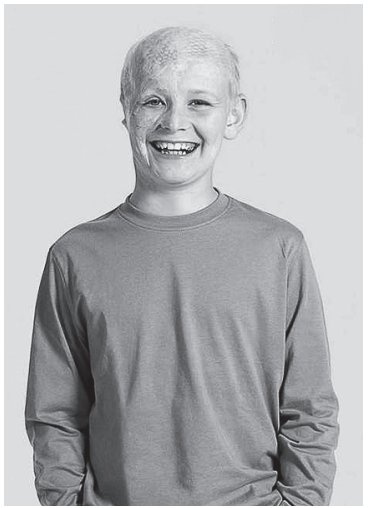

C 血管腫

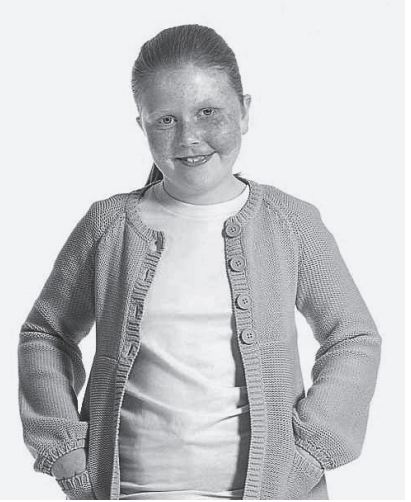

Appendix Figure 1 写真刺激

注）質問紙では各写真刺激縦 $85.06 \mathrm{~mm}$ とし, Changing Facesの許可を得てカラーで提示した。

\section{文 献}

1) 後藤昌昭 - 古郷幹彦 - 西尾順太郎 - 他, 口唇裂 - 口蓋裂 診療ガイドライン，日本口腔外科学会，2009. 
2) Julian, D., \& Partridge, J., The incidence and prevalence of disfigurement. London: Changing Faces, 2008.

3）近藤佳代子 · 遠藤雄一郎 - 藤田政博, 顔の異形が当事者 にもたらす心理社会的影響に関する文献的考察. 日本健 康教育学会誌 13(1), 46-53, 2005.

4) 松本学, 容貌の自己受容一口唇 · 口蓋裂の場合一. 現代 文明学研究 2, 88-106, 1999.

5) 西倉実季, 異形の人々の対処方略—顔にあざのある女性 のライフストーリーからー。 年報社会学論集 21, 37-48, 2008.

6) 石井政之,「異形の人」をとりまく現状一日本と海外の 比較一. 看護学䧱誌 64(5), 402-406, 2000.

7) 石井政之・藤井輝明・松本学, 見つめられる顔一ユニー クフェイスの体験一. 高文研, 2001.

8) Rumsey, N., \& Harcourt, D., Visible difference amongst children and adolescents: issues and interventions. Developmental Newrorehabillitation 10(2), 113-123, 2007.

9) 松本学, 口唇裂口蓋裂児の自己の意味づけの特徵. 発達 心理学研究 20(3), 234-242, 2009.

10) Bull, R., \& Rumsey, N., The Social Psychology of Facial Appearance. London: Springer, 1988. (仁平義明監訳, 人 間にとって顔とは何か一心理学から見た容貌の影響一. 講談社, 1995.)

11) Kondo, K., \& Yamazaki, Y., Living with facial disfigurement: Stigmatizing situations, coping strategies and their influence on psychological well-being. Jpn J Health E Human Ecology 71(4), 142-156, 2005.

12) Changing Faces, Disfigurement in the UK. London: Changing Faces, 2017.

13) 松本学, 第 9 章 可視的変形と質的研究 : 希少な疾患の 心理学的研究に向けて. 遠藤利彦・坂上裕子編, よくわ 加質的心理学：生涯発達. 東京図書, 2007.

14) 松本学, ユニークフェイスとは何か. 部落解放 479, 98109, 2001.

15）西倉実季，公/私の境界を引き直す一個人的な経験を排 除しない「障害の社会モデル」であるために一，質的心 理学フォーラム 7, 58-65, 2015.

16）水野敬也，顔ニモマケズ一どんな「見た目」でも幸せに なれることを証明した 9 人の物語一，文響社， 2017.

17）高橋聖人・茅島奈緒深, ジロジロ見ないで—“普通の顔” を峦った 9 人の物語一。扶桑社, 2003 .

18）松本学, 顔の変形を有する人をとりまく環境とその支援 一Changing Faces ワークショップの試み 第一回一. ヒューマンライッ 192, 48-51, 2004.

19）坂梨左織・大池美也子, 口唇口蓋形成術を受けた子ども の母親の経験. 日本看護研究学会雑誌 33(4), 85-95, 2010.

20）深野英夫 ·夏目長門 - 鈴木俊夫 ·他, 口唇, 口蓋裂児を もつ家族, 特に母親の心理一II. CMI からみた口唇,
口蓋裂児出産後の母親の心理一. 日口蓋誌 10(2), 206212, 1985.

21) 松本学, 第 5 章 顔に違いがあるということ 先天的な 変形を中心にして. 田垣正晋編, 障害·病いと「ふつう」 のはざまで。明石書店, 2006

22) Richman, L. C., The Effects of Facial Disfigurement on Teacher's Perception of Ability in Cleft Palate Children. Cleft Palate Journal 15(2), 155-160, 1978.

23) Houston, V., \& Bull, R., Do people avoid sitting next to someone who is facially disfigured?. European Journal of Social Psychology 24, 279-284, 1994.

24) Stock, N. M., Whale, K., Jenkinson, E., et al., Young people's perceptions of visible difference. Diversity and Equality in Health and Care 10, 41-51, 2013.

25）林文俊, 対人認知構造の基本次元についての一考察. 名 古屋大学教育学部紀要 (教育心理学科) 25, 233-247, 1978.

26) 井上正明, 小林利宣, 日本における SD 法による研究分 野とその形容詞対尺度構成の概観. 教育心理学研究 33(3), 253-260, 1985.

27) 松本学・石井政之・藤井輝明, 知っていますか? ユニー クフェイス一問一答. 解放出版社, 2001.

28) 梶井正 - 黒木良和 - 新井詔夫, 新 先天奇形症候群ア卜 ラス一改訂第 2 版一. 南江堂, 2015.

29）鈴木俊夫 ·服部吉幸 · 加藤正樹 - 他, 口唇 - 口蓋裂児に 対する地域社会の認識について。 日口蓋誌 4(2), 63-75, 1979.

30) Mayring, P., QUALITATIVE FORSCHUNG. Flick, U. Hamburg: Rowohlt Verlag, 1995. (小田博志 - 山本則子 春日常・他訳 質的研究入門一〈人間の科学〉のための 方法論一. 春秋社, 2002.)

31) 今田純雄, 感情の三次元モデル. 中島義明 · 安藤清志 · 子安増生・他編, 心理学辞典. 有斐閣, 2003.

32) Stevenage, S. V., \& McKay, Y, Model applicants: The effect of facial appearance on recruitment decisions. British Journal of Psychology 90, 221-234, 1999.

33) 藤井輝明, 顔とトラウマ一医療・看護 · 教育における実 践活動一. かもがわ出版, 2001.

34) Rhodes, G., Hayward, W. G., \& Winkler, G., Expert face coding: Configural and component coding of own-race and other-race faces. Psychonomic Bulletine Review 13(3), 499-505, 2006.

35) Grandfield, T. A., Thompson, A. R., \& Turpin, G., An Attitudinal Study of Responses to a Range of Dermatological Conditions Using the Implicit Association Test. Journal of Health Psychology 10(6), 821-829, 2005.

36) Lippa, R. A., The Preferred Traits of Mates in a CrossNational Study of Heterosexual and Homosexual Men 
and Women: An Examination of Biological and Cultural Influences. Arch Sex Behav 36, 193-208, 2007.

37) 石井政之, 顔面漂流記一アザをもつジャーナリストー. かもがわ出版, 1999.

38）藤井輝明，あなたは顔で差別をしますか一「容㜔障害」 と戦った五十年一. 講談社, 2008.

39) Changing Faces, FACE EQUALITY TEACHING RESOURCES FOR KEY STAGE 3. London: Changing Faces, 2011.

40) Partridge, J., Changing Faces: The Challenge of Facial
Disfigurement. London: Penguin, 1990 (原田輝一, チェ ンジング・フェイスーもっと出会いを素晴らしく一. 集 英社, 2002.)

41) Partridge, J., The psychological effects of facial disfigurement: A study of the aftermath of facial disfigurement and a report of an initiative to tackle the inner scars of that experience. Journal of wound care 2(3), 168-171, 1993.

42) 松本学, 顔の変形を有する人をとりまく環境とその支援 一Changing Faces ワークショップの試み 第三回一. ヒューマンライツ 194, 46-49, 2004. 